Reprod. Nutr. Dévelop., 1982, 22 (4), 641-650.

\title{
Hormone levels in plasma of ewes induced into lactation
}

\author{
H. H. HEAD $\left({ }^{1}\right)$, C. DELOUIS $\left({ }^{*}\right)\left({ }^{2}\right), J . \operatorname{FEVRE}(*), G . \operatorname{KANN}\left({ }^{*}\right)$, \\ M. TERQUI $\left({ }^{* *}\right)$, J. DJIANE $\left({ }^{*}\right)$ \\ with the technical assistance of J. PONT, M. MARCEL, P. BOLIFRAUD, B. BONICEL
}

Dairy Science Department, University of Florida, Gainesville, Florida 32611, U.S.A.

(*) Laboratoire de Physiologie de la Lactation, I.N.R.A., 78350 Jouy-en-Josas, France.

(**) Station de Physiologie de la Reproduction, I.N.R.A., Nouzilly, 37380 Monnaie, France.

Summary. A short-term treatment with estradiol-17 $\beta$ and progesterone induced mammary gland growth and lactogenesis in non-pregnant ewes. These events normally occur during the second half of pregnancy. In order to compare the hormonal environment during the treatment to that during pregnancy, the concentrations of total estrogens $(T E)$, progesterone $\left(P_{4}\right)$, glucocorticoids $(G)$ and prolactin (Prl) in the plasma were characterized in non-pregnant, intact ewes induced into lactation with subcutaneous injections of estradiol- $17 \beta\left(E_{2}-\beta\right)$ and $P_{4}$ for 7 consecutive days (days 1 to 7 ).

Eight non-pregnant, intact, multiparous ewes were divided into two groups (groups I and II, 4 ewes each), according to their milk yields recorded during the previous lactation. All the ewes received the short-term treatment with $E_{2}-\beta$ and $P_{4}$; the ewes of group II were also injected with hydrocortisone acetate $(\mathrm{H})$ and growth hormone $(\mathrm{GH})$ twice daily on days 18 to 20 . Blood was collected twice daily for 21 days and milking was initiated 19 days after the first injection of $E_{2}-\beta$ and $P_{4}$. Concentrations of $T E, P_{4}, G$ and Prl were measured in the plasma of ewes in group I but only $G$ and $\mathrm{Prl}$ were measured in the plasma of the ewes in group II. Two ewes of group I and one of group II failed to lactate. Mean milk yields $(2.5 \pm 0.4$ and $6.3 \pm 0.9 \mathrm{~kg} / 34$ days) were highest when injections of $\mathrm{H}$ and $\mathrm{GH}$ were included.

Average pretreatment concentrations of plasma TE and $P_{4}$ were $3.1 \pm 0.8$ and $2.1 \pm 0.4 \mathrm{ng} / \mathrm{ml}$, respectively; these increased to $10.2 \pm 1.3$ and $5.6 \pm 0.6 \mathrm{ng} / \mathrm{ml}$ during the week of the $E_{2}-\beta$ and $P_{4}$ injections. Peak concentrations occurred on days 7 and 6 , respectively, and the plasma levels had returned to pretreatment values by days 18 to 20 . Concentrations of $G$ in plasma were higher $(13.0 \pm 1.0 \mathrm{ng} / \mathrm{ml})$ during $E_{2}-\beta$ and $P_{4}$ injections than during pre- or post-injection $(7.4 \pm 1.4$ and $8.2 \pm 0.7 \mathrm{ng} / \mathrm{ml}$, respectively). Plasma Prl showed biphasic two to six-fold increases on days 4 and 7 during $E_{2}-\beta$ and $P_{4}$ injections and thereafter declined to lower average daily concentrations on days 10 to 13 . Plasma Prl began to increase, and its average concentration was $579 \pm 56 \mathrm{ng} / \mathrm{ml}$ by days 18 to 20 .

These results suggest that the amount of the $P_{4}$ injections should be increased and that the treatment with $E_{2}-\beta$ and $P_{4}$ should last long enough to insure the induction of an endocrine balance which would correspond more accurately to the hormonal events occurring during the second half of pregnancy in the ewe.

(1) Florida Agr. Expl. Stat. Journal Series no 1812.

(2) To whom correspondence should be send. 


\section{Introduction.}

Lactation was induced in non-pregnant intact and ovariectomized ewes by a two-phase hormone injection scheme (Fulkerson and McDowell, 1974, 1975; Fulkerson et al., 1975, 1976, 1977). The mammary glands of the ewes were developed by injections of estradiol benzoate and progesterone $\left(P_{4}\right)$ for 30 or 60 days (phase 1). Lactation was then initiated by milking or by injections of estradiol benzoate alone or with $\mathrm{P}_{4}$ or by injections of dexamethasone, oxytocin or prostaglandin (phase 2). Although milk yields increased rapidly, they were still less than those of ewes lactating after lambing, and the number of ewes which lactated after treatment was variable. The ewes were also induced to lactate after injections of estradiol- $17 \beta\left(E_{2}-\beta\right)$ and $P_{4}$ at doses $(0.5$ and $1.25 \mathrm{mg} / \mathrm{kg}$ body weight/day, respectively) similar to (D'Amico et al., 1976; Alifakiotis et al., 1980) or five-fold higher (Head et al., 1980) than those used to induce cows into lactation (Smith and Schanbacher, 1973; Erb et al., 1976; Chakriyarat et al., 1978 ; Delouis et al., 1978). In these studies, the milk yields of induced ewes were less than after lambing, and the number of animals responding to the treatment varied. Milk yields of induced lactations, expressed as percentages of those during natural lactation, were generally less in ewes than in cows.

The causes of variable response have been only partially delineated. Adding hydrocortisone to the hormone regime increased lactation yields and the number of animals induced to lactate (Alikakiotis et al., 1980; Head et al., 1980), whereas milking or additional hormone injections did not improve the results. Fulkerson et al. $(1975,1976)$ found that high concentrations of $P_{4}$ inhibited $\mathrm{Prl}$ release. In cows, high milk production after induction was associated with below-average concentrations of estrogens and $\mathrm{P}_{4}$ at the start of injection, rapid decreases in $\mathrm{P}_{4}$ after day 7 and in estrogens after day 14 , and decreased concentrations of Prl after day 7 (Erb, 1977).

The aim of the present study was to characterize the changes in the concentrations of total estrogens (TE), $P_{4}, \mathrm{Prl}$ and glucocortidoids $(G)$ in ewes induced into lactation by injections of $E_{2}-\beta$ and $P_{4}$. The knowledge gained could modify the injection protocols used to induce lactation and improve our understanding of mammogenesis and lactogenesis.

\section{Material and methods.}

Animals. - Eight multiparous ewes of the Préalpes-du-Sud breed were permanently housed. They were fed corn, barley, peas and hay according to a production of $0.5 \mathrm{~kg}$ milk/day. A natural light regimen (March) was used.

Experimental procedure. - The ewes were divided into two groups (I and II) according to their milk yields $(25 \pm 2$ and $23 \pm 3 \mathrm{~kg}$ of milk, respectively, during 28 days after lambing) recorded during the previous lactation. The ewes in both groups received subcutaneous injections of half-doses 10.5 and $1.25 \mathrm{mg} / \mathrm{kg}$ body weight/day) of $E_{4}-\beta$ and $P_{4}$, respectively, twice daily at 8 a.m. and 5 p.m. for 
7 days (days 1 to 7), while the ewes in group II received, in addition, injections of hydrocortisone acetate $(\mathrm{H}, 25 \mathrm{mg}$ ) and growth hormone (GH; $15 \mathrm{mg}$ ) twice a day on days 18 to 20 . Hand milking was initiated on day 19 and machine milking on day 26 at 7:30 a.m. and 4:30 p.m. for 24 days. The milk yields were recorded 5 days a week throughout lactation.

$E_{2}-\beta$ and $P_{4}$ (Roussel, Paris, France) were dissolved in 95 p. 100 alcohol. Hydrocortisone acetate (Roussel) was injected as supplied by the manufacturer, and ovine GH (Byla, Paris, France ; $2 \mathrm{lU} / \mathrm{mg}$ ) was dissolved in a small amount of $\mathrm{NaOH} 0.001 \mathrm{~N}$ and diluted in saline before injection.

Blood sampling. - Blood samples were collected from 2 days before until 21 days after $E_{2}-\beta$ and $P_{4}$ injections. The blood was collected via jugular venipuncture into heparinized vacutainer tubes (vacutainer, $5 \mathrm{ml}$, Becton Dickinson, Pont-de-Claix, France) twice a day, at 7 a.m. and 4 p.m., prior to the daily hormone injections or milking. Plasma was obtained by centrifugation at $4{ }^{\circ} \mathrm{C}$ and frozen at $-20^{\circ} \mathrm{C}$ until required for hormone analysis.

Hormone analysis. - Total plasma estrogens (TE), expressed as estrone equivalents, were estimated by radioimmunoassay according to Terqui et al. (1973) and Palmer and Terqui (1977). Progesterone was assayed according to Bosc and Fèvre (1975) and Palmer and Jousset (1975) and glucocorticoids according to Fèvre (1975) and Bosc and Fèvre (1977). Hydrocortisone acetate did not cross-react in this radioimmunoassay.

Prolactin concentrations were measured by the method described by Kann (1971). Prolactin $(\mathrm{NIH}, \mathrm{PS} 7 ; 24.8 \mathrm{IU} / \mathrm{mg}$ ) was used to prepare the standard curves in the presence of hypophysectomized ewe serum in amounts similar to those of the unknown.

In group I ewes, plasma TE concentrations were determined in samples taken up to day 19 and plasma $\mathrm{P}_{4}$ concentrations in those taken up to day 12 . The concentrations of $G$ in plasma were determined in all the samples from the ewes in both groups, except in those of two ewes per group where only the 4 p.m. sample was analyzed. Plasma Prl was assayed in all the samples of both groups.

\section{Results.}

Milk yields. - The mean milk yields $(2.5$ and $6.1 \mathrm{~kg})$ for the 34-day lactations were significantly lower $(P<0.01)$ for the ewes in group I thant in group II. Two ewes in group I and one ewe in group II failed to lactate. Two ewes in group I and three in group II had a mean production of more than $100 \mathrm{ml} /$ day, while two ewes in group II produced more than $200 \mathrm{ml} /$ day. The lactation characteristics are shown in figure 1.

Estrogens and progesterone. - The concentrations of TE and $\mathrm{P}_{4}$ in the plasma of the group 1 ewes are shown in figures 2 and 3 . The average concentrations of TE and $P_{4}$ increased two to three-fold during the time of injection. Those of individual ewes increased 2.2 to 5.7 -fold. Peak concentrations were found on day 7 for TE $(21.6 \mathrm{ng} / \mathrm{ml})$ and on day 6 for $P_{4}(9.7 \mathrm{ng} / \mathrm{ml})$. 


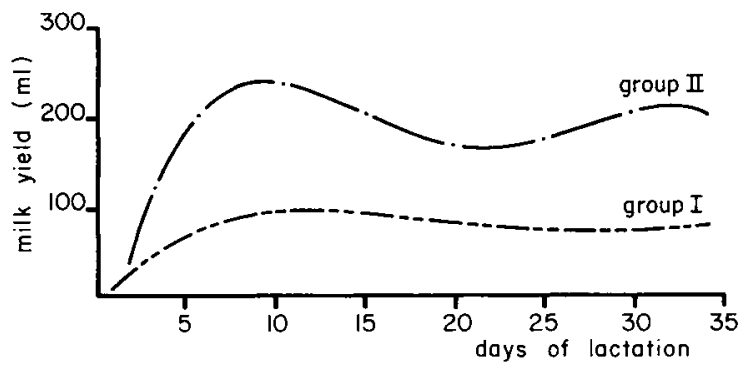

FIG. 1. - Milk yield regressions of ewes induced into lactation. The ewes in both groups received injections of estradiol-17 $\beta$ and progesterone for 7 days, while those in group II also received injections of hydrocortisone and growth hormone (for details see Material and methods). 4 ewes in each group.

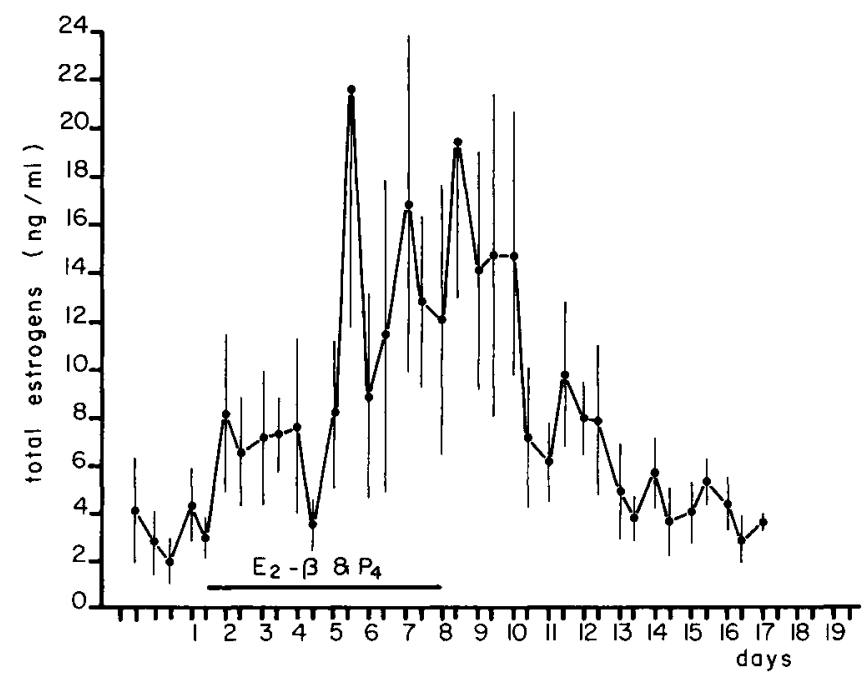

FIG. 2. - Concentrations of total estrogens in the plasma of ewes induced into lactation with estradiol-17 $\beta$ and progesterone injections. Milking was initiated on day 21. The points and vertical lines represent the means \pm SEM. (Group II).

Quartic regressions (not shown) revealed that the increases in the concentrations of TE and $P_{4}$ were essentially the same as in dairy cows receiving $E_{2}-\beta$ and $P_{4}$ to induce lactation (Charkiyarat et al., 1978; Delouis et al., 1978), but that the magnitude of those increases in ewes was equivalent to a five-fold increase in the hormone dose injected per $\mathrm{kg}$ of body weight. Plasma TE and $\mathrm{P}_{4}$ levels returned to preinjection concentrations by the day milking began. There was no significant difference between the morning and afternoon samples as to TE and $\mathrm{P}_{4}$ concentrations. 


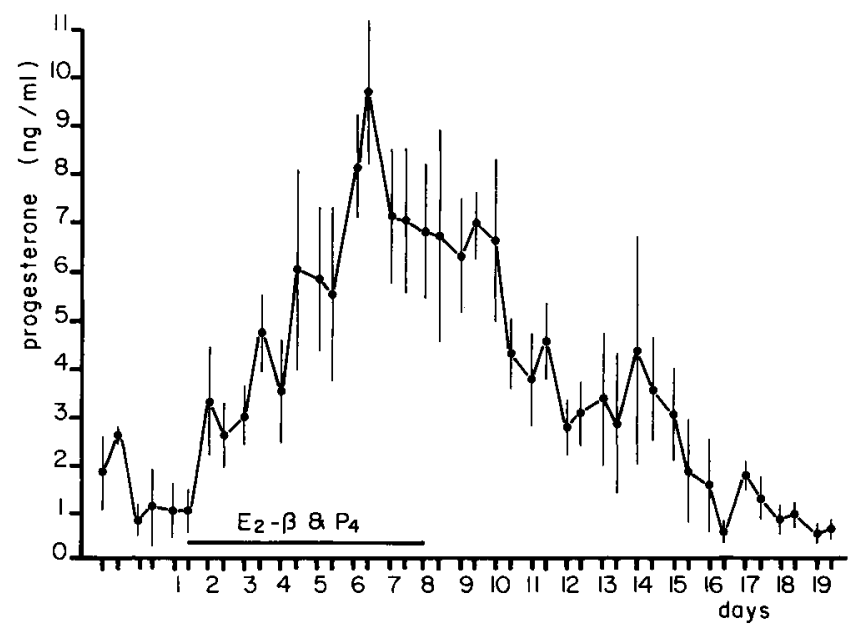

FIG. 3. - Concentrations of progesterone in the plasma of ewes induced into lactation with estradio/-17 $\beta$ and progesterone injections. Milking was initiated on day 21 . The points and vertical lines represent the means \pm SEM. (Group II).

Glucocorticoids. - Average concentrations of $\mathrm{G}$ in plasma tended to increase during $E_{2}-\beta$ and $P_{4}$ treatment (table 1 ) but not significantly. The average concentrations were significantly higher in a.m. than in p.m. samples. There was no significant difference between groups I and II.

TABLE I

Average concentrations of hormones in plasma of ewes during induction of lactation using estradiol-17 $\beta\left(\mathrm{E}_{2}-\beta\right)$ and progesterone $\left(\mathrm{P}_{4}\right)$ (group I)

\begin{tabular}{cccccc}
\hline Days & 1 to 3 & 4 to 10 & 11 to 17 & 18 to 20 \\
\hline Hormone & Preinjection & $\begin{array}{c}\text { During steroid } \\
\text { injections }\end{array}$ & $\begin{array}{c}\text { Post } \\
\text { injection }\end{array}$ & Pre-milking \\
\cline { 2 - 5 } & & \multicolumn{3}{c}{$(\mathrm{ng} / \mathrm{ml})$} \\
Glucocorticoids & $\ldots \ldots \ldots \ldots$ & $\begin{array}{c}7.4 \pm 1.4(16)^{\mathrm{a}} \\
(2.4-27.4)^{\mathrm{b}}\end{array}$ & $\begin{array}{c}13.3 \pm 1.0(41) \\
(3.3-27.5)\end{array}$ & $\begin{array}{c}8.2 \pm 0.7(44) \\
(2.5-22.1)\end{array}$ & $\begin{array}{c}6.2 \pm 1.0(17) \\
(1.8-13.6)\end{array}$ \\
Prolactin & $\ldots . \ldots \ldots \ldots \ldots$ & $\begin{array}{c}202 \pm 23(20) \\
(49-401)\end{array}$ & $\begin{array}{c}407 \pm 58(55) \\
(77-2217)\end{array}$ & $\begin{array}{c}339 \pm 30(60) \\
(79-1207)\end{array}$ & $\begin{array}{c}579 \pm 56(24) \\
(191-1078)\end{array}$ \\
\hline
\end{tabular}

${ }^{a}$ Mean \pm SEM ; no. of samples in parentheses includes a.m. and p.m. samples. ${ }^{b}$ Range of concentrations.

Prolactin. - The average concentrations of plasma Prl increased during injections of $E_{2}-\beta$ and $P_{4}$, declined after the injections stopped, then rose again to reach a new peak on days 18-19 (fig. 4). One day after the first $E_{2}-\beta$ and $P_{4}$ injection, 4 ewes in group I and 3 in group II showed a two to six-fold increase in plasma Prl. Peak concentrations (all ewes) averaged $1317 \pm 350 \mathrm{ng} / \mathrm{ml}$ 


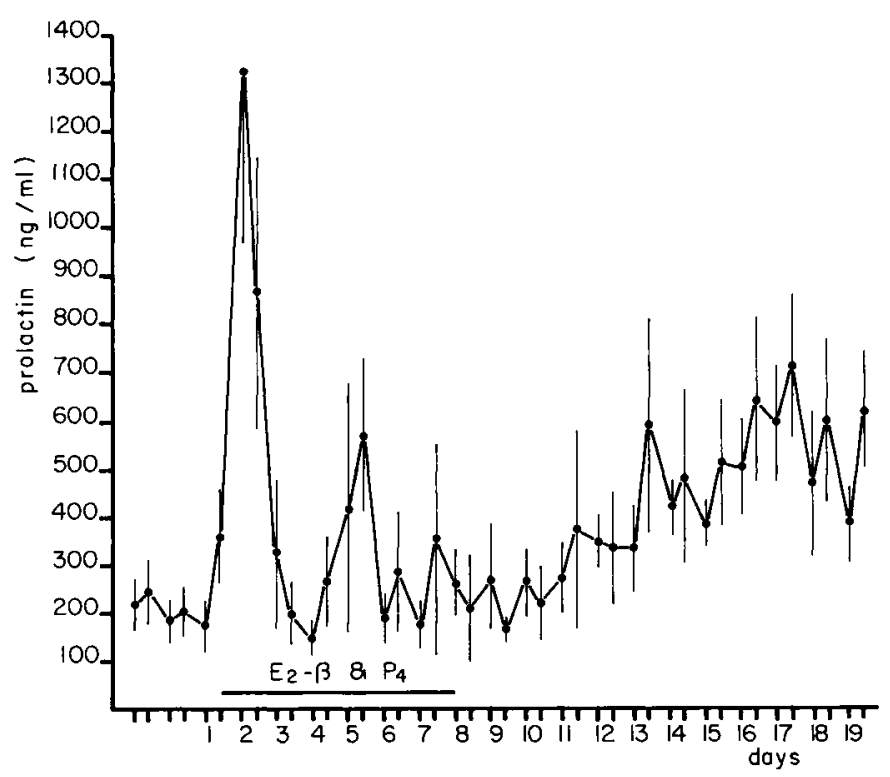

FIG. 4. - Concentrations of prolactin in the plasma of ewes induced into lactation with estradiol-17 $\beta$ and progesterone injections. Milking was initiated on day 21. The points and vertical lines represent the means \pm SEM. (Group II).

(range : 605 to $2217 \mathrm{ng} / \mathrm{ml}$ ). A two to three- fold increased occurred in 2 ewes in each group on day 4 of the $E_{2}-\beta$ and $P_{4}$ treatment. Thereafter, $\mathrm{Prl}$ was variable but tended to decrease until day 9 , then gradually increased until milking was initiated (fig. 4). The average concentrations were higher $(P<0.01)$ during the premilking period $(578 \pm 56)$ than immediately after the $E_{2}-\beta$ and $P_{4}$ treatment $(300 \pm 30 \mathrm{ng} / \mathrm{ml})$. The pattern of the change in plasma Prl in groups I and II and the average Prl concentrations of the a.m. and p.m. samples were not significantly different. There appeared to be no relationships between the plasma hormone concentrations and the milk yields either within or between the groups.

\section{Discussion.}

Subcutaneous injections of $E_{2}-\beta$ and $P_{4}(0.5$ and $1.25 \mathrm{mg} / \mathrm{kg}$ body weight) induced fewer ewes into lactation than similar schemes used with cows (Smith and Schanbacher, 1973 ; Erb et al., 1976 ; Chakriyarat et al., 1978 ; Delouis et al., 1978). The average milk yields of 76 ewes induced into lactation were only 25 to 30 p. 100 of those of ewes in the flock which lactated after lambing (Head et al., 1980) ; these data agree with previous results (Fulkerson et al., 1974, 1976). The lower efficacy of steroid injections in ewes, as compared to cattle, may be associated with the failure of short-term $E_{2}-\beta$ and $P_{4}$ injections to mimic the hormonal profiles of late pregnancy.

The average concentrations of plasma $\mathrm{TE}, \mathrm{P}_{4}, \mathrm{G}$ and $\mathrm{Prl}$ in ewes during induction of lactation were generally proportionally higher than in cows receiving 
$E_{2}-\beta$ and $P_{4}$ injections. The pattern of change in plasma $G$ and $P r l$ in ewes did not differ markedly from that of cows (Erb et al., 1976 ; Chakriyarat et al., 1978 ; Delouis et al., 1978), except for the biphasic increase in Prl detected during steroid injections (fig. 4) (Fulkerson et al., 1976). Biphasic Prl release probably resulted from a modified anterior pituitary response to $E_{2}-\beta$ when $P_{4}$ was also elevated. Kann and Denamur (1973) observed a biphasic Prl release when estradiol was injected on day 11 of the estrous cycle but not when it was injected on day 3 . The higher concentrations of plasma $\mathrm{Prl}$ in cycling or anestrous ewes were associated with increased plasma estrogen at estrus (Reeves et al., 1970) or after $E_{2}-\beta$ injections or infusions (Fell et al., 1972). Thus, $\mathrm{Prl}$ release, provoked by $\mathrm{E}_{2}-\beta$ during induction, may be mutec by high concentrations of plasma $P_{4}$ until the relative $P_{4}$ concentration declines (days 10 to 13) (fig. 3).

Changes in the prepartum plasma hormone concentrations have been described in ewes (Bedford et al., 1972 ; Stabenfeldt et al., 1972 ; Chamley et al., 1973; Kann and Denamur, 1974). The abrupt rise in total circulating estrogens 1 to 2 days before lambing and the decrease in $P_{4}$ concentrations during the preceding week contrasts with the essentially simultaneous increase and decrease in ewes induced into lactation (figs. 2, 3). Furthermore, Prl increase during induced lactation was more gradual and its magnitude was less than at lambing, whereas $G$ concentrations were variable throughout induction and increased only at the time of milking in ewes injected with hydrocortisone acetate.

Decreases in TE and $\mathrm{P}_{4}$ in the plasma of induced ewes precede the apparent increases in mammary gland size (Fulkerson and McDowell, 1974 ; Head et al., 1980 ) and increases in the nucleic acid content of the mammary gland (Delouis et al., 1980). As in cows (Chakriyarat et al., 1978), these events seem closely associated with elevated concentrations of $\mathrm{Prl}$ and a decrease in plasma TE and $\mathrm{P}_{4}$ concentrations.

Concentrations of $\mathrm{G}$ in plasma during injections were within the prepartum range between 10 and $20 \mathrm{ng} / \mathrm{ml}$ (Chamley et al., 1973). Although variable, $\mathrm{Prl}$ concentrations were generally higher $(>100 \mathrm{ng} / \mathrm{ml})$ throughout induced lactation than those observed during the last month of pregnancy. When milking was initiated, the concentrations were equivalent to those at parturition (100 to $640 \mathrm{ng} / \mathrm{ml}$ ) (Chamley et al., 1973 ; Kann et al., 1978). This suggests that Prl was not limiting when milking was initiated in ewes induced into lactation. A simultaneous rise in Prl and $\mathrm{G}$ seems to be important for lactogenesis since milk yields were enhanced in ewes receiving hydrocortisone acetate injections concurrently with the Prl surge after caesarian section on day 141 of pregnancy (Kann et al., 1978). The synergistic role of $G$ and Prl in lactogenesis has been demonstrated in vivo. Injections of a glucocorticoid into pregnant ewes induced lactogenesis while Prl did not (Delouis and Denamur, 1967), but blocking the $\mathrm{Prl}$ rise with bromocriptine markedly reduced lactogenesis in non-pregnant ewes receiving a short-term treatment of $E_{2}-\beta$ and $P_{4}$ (Fulkerson et al., 1975). The importance of a synchronous increase of $\mathrm{G}$ and $\mathrm{Prl}$ is also inferred from the present study and by Fulkerson and McDowell (1974). Hydrocortisone injection 
when Prl was high (days 18 to 20 ) (table 1) also increased the number of ewes induced into lactation and, subsequently, the milk yield, whereas injections of $G$ thyroxine did not (Head et al., 1980).

Reducing the true amount of steroids injected does not reduce the effectiveness of induction (D'Amico et al., 1977), and no improvement resulted from injecting for a longer period (Fulkerson and co-workers, 1974, 1975, 1976), but a consideration of all the hormone data obtained does provide some insight into probable ways of improvement. The amount of $P_{4}$ injected relative to $E_{2}-\beta$ should be increased, and the $E_{2}-\beta$ injections given for a longer time. This would more closely synchronize increases in $\mathrm{TE}$ and $\mathrm{Prl}$ and the decrease in $\mathrm{P}_{4}$ to coincide with the $G$ injections prior to initiating milking. These suggested modifications are consistent with those proposed by Erb (1977) based upon associations between plasma hormone concentrations and milk yield in cows having high lactations induced by $E_{2}-\beta$ and $P_{4}$ injections. Also, closer approximation to prepartum hormonal profiles should provide a model for studying mammogenesis and lactogenesis in the ewe in the absence of the endocrine influence of the fetoplacental unit.

Reçu en septembre 1981. Accepté en mars 1982.

Résumé. Un traitement de courte durée par l'oestradiol-17 $\beta$ et la progestérone induit la croissance de la glande mammaire et la montée laiteuse chez la brebis non gravide. Ces événements surviennent normalement pendant la deuxième moitié de la gestation. Afin de comparer les équilibres endocriniens existants pendant le traitement et pendant la gestation, les variations des concentrations plasmatiques des œestrogènes totaux (TE), de la progestérone $\left(P_{4}\right)$, des glucocorticoïdes $(G)$ et de la prolactine (Prl) ont été mesurées chez la brebis non gravide dont la lactation est induite par des injections sous-cutanées d'œstradiol-17 $\beta\left(E_{2}-\beta\right)$ et de $P_{4}$ pendant 7 jours consécutifs (jours 1 à 7 ).

Huit brebis multipares, taries, non gravides sont réparties en deux groupes (groupes I et II, 4 brebis/groupe) en tenant compte de la production laitière de la lactation précédente. Toutes les brebis sont soumises à un traitement de courte durée $d^{\prime} E_{2}-\beta$ et de $\mathrm{P}_{4}$; les brebis du groupe II reçoivent, en plus, des injections biquotidiennes d'acétate d'hydrocortisone $(\mathrm{H})$ et d'hormone de croissance $(\mathrm{GH})$ du jour 18 au jour 20 . Des prises de sang biquotidiennes sont réalisées pendant 21 jours et la traite commence 19 jours après la première injection $d^{\prime} E_{2}-\beta$ et de $P_{4}$. Les concentrations de $T E, P_{4}, G$ et $\mathrm{Prl}$ ont été déterminées dans les plasmas des brebis du groupe $\mathrm{I}$; seules les concentrations de $\mathrm{G}$ et de Prl ont été mesurées dans les plasmas des brebis du groupe II. Deux brebis du groupe I et une du groupe II n'ont pas eu de montée laiteuse. Les productions laitières moyennes sont plus élevées après administration de $\mathrm{H}$ et de $\mathrm{GH}(2,5 \pm 0,4$ et $6,3 \pm 0,9 \mathrm{~kg} / 34$ jours, groupes I et II, respectivement).

Les concentrations plasmatiques moyennes de TE et de $\mathrm{P}_{4}$ avant le traitement étaient, respectivement $3,1 \pm 0,8$ et $2,1 \pm 0,4 \mathrm{ng} / \mathrm{ml}$; elles s'élèvent à $10,2 \pm 1,3$ et $5,6 \pm 0,6 \mathrm{ng} / \mathrm{ml}$ durant les 7 jours d'administration $d^{\prime} E_{2}-\beta$ et de $P_{4}$. Les concentrations maximales sont observées respectivement les jours 7 et 6 et les taux plasmatiques sont revenus, entre les jours 18 et 20 , à des valeurs comparables à celles observées avant le traitement. Les concentrations plasmatiques de $\mathrm{G}$ sont plus élevées pendant les injections $\mathrm{d}^{\prime} E_{2}-\beta$ et de $\mathrm{P}_{4}(13,0 \pm 1,0 \mathrm{ng} / \mathrm{ml})$ qu'avant ou après les injections $(7,4 \pm 1,4$ et $8,2 \pm 0,7 \mathrm{ng} / \mathrm{ml}$, respectivement). La prolactinémie augmente entre 2 et 6 fois, de façon biphasique, les jours 4 et 7 pendant les injections $d^{\prime} E_{2}-\beta$ et de $P_{4}$, puis elle diminue. Les 
valeurs moyennes les plus faibles sont observées entre les jours 10 et 13 . La prolactinémie a augmenté après le jour 13 pour atteindre une valeur moyenne de $579 \pm 56 \mathrm{ng} / \mathrm{ml}$ entre les jours 18 et 20.

Ces résultats suggèrent d'augmenter la quantité de $P_{4}$ administrée et de prolonger la durée du traitement $E_{2}-\beta$ et $P_{4}$ pour réaliser un équilibre endocrinien plus proche de celui présent pendant la deuxième moitié de la gestation chez la brebis.

\section{References}

ALIFAKIOTIS T. A., KATANOS I., HATJIMINAOGLOU I., ZERVAS N., ZIRFIRIDIS G., 1980. Induced lactation in dairy ewes by various brief hormone treatments. J. Dairy Sci., 63, 750-755.

BEDFORD C. A., CHALLIS J. R. G., HARRISON F. A., HEAP R. B., 1972. The role of oestrogens and progesterone on the onset of parturition in various species. J. Reprod. Fertil., Suppl. 16, 123.

BOSC M., FEVRE J., 1975. Evolution de la progestéronémie chez la brebis en fin de gestation après destruction de l'hypophyse fœetale. Effet d'une administration de dexaméthasone. C.R. Acad. Sci. Paris, sér. D, 281, 559-562.

BOSC M., FĖVRE J., 1977. Evolution de la cortisolémie au cours de la première semaine de vie chez le veau et chez l'agneau. C.R. Acad. Sci. Paris, sér. D, 284, 2373-2376.

CHAKRIYARAT S., HEAD H. H., THATCHER W. W., NEAL F. C., WILCOX C. J., 1978. Induction of lactation : lactational, physiological and hormonal responses in the bovine. J. Dairy Sci., 61, 1715-1724.

CHAMLEY W. A., BUCKMASTER J. M., CERINI M. E., CUMMING I. A., GODING J. R., OBST J. M., WILLIAMS A., WINFIELD C., 1973. Changes in the levels of progesterone, corticosteroids, estrone, estradiol-17 $\beta$, luteinizing hormone, and prolactin in the peripheral plasma of the ewe during late pregnancy and at parturition. Biol. Reprod., 9, 30-35.

D'AMICO M. F., ERB R. E., MALVEN P. V., 1976. Effect of TRH on induction of lactation in ewes pretreated with ovarian steroids. J. Dairy Sci. (Suppl. 1), 59, 141 (Abstr.).

DELOUIS C., DENAMUR R., 1967. Induction expérimentale de la sécrétion lactée pendant la gestation de la brebis C.R. Acad. Sci. Paris, sér. D, 264, 2493-2496.

DELOUIS C., DJIANE J., KANN G., TERQUI M., HEAD H. H., 1978. Induced lactation in cows and heifers by short-term treatment with steroid hormones. Ann. Biol. anim. Bioch. Biophys., 18, 721-734.

DELOUIS C., DJIANE J., HOUDEBINE L. M., TERQUI M., 1980. Relation between hormones and mammary gland function. J. Dairy Sci., 63, 1492-1513.

ERB R. E., 1977. Hormonal control of mammogenesis and onset of lactation in cows. A review. J. Dairy Sci., 60, 155-169.

ERB R. E., MONK E. L., MOLLETT T. A., MALVEN P. V., CALLAHAN C. J., 1976. Estrogen, progesterone, prolactin and other changes associated with bovine lactation induced with estradiol-17 $\beta$ and progesterone. J. anim. Sci., 42, 644-654.

FELL L. R., BECK C., BROWN J. M., CATT K. J., CUMMING I. A., GODING J. R., 1972. Solidphase radioimmunoassay of ovine prolactin in antibody-coated tubes. Prolactin secretion during estradiol treatment, at parturition and during milking. Endocrinology, 91, 1329-1336.

FĖVRE J., 1975. Corticostéroïdes maternels et fœtaux chez la truie en fin de gestation. C.R. Acad. Sci. Paris, sér. D, 281, 2009-2012.

FULKERSON W. J., McDOWELL G. H., 1974. Artificial induction of lactation in ewes. J. Endocrinol., 63, 167-173.

FULKERSON W. J., McDOWELL G. H., 1975. Artificial induction of lactation in ewes. The relative importance of oxytocin and the milking stimulus. Aust. J. biol. Sci., 28, 521-524.

FULKERSON W. J., McDOWELL G. H., FELL L. R., 1975. Artificial induction of lactation in ewes : the role of prolactin. Aust. J. biol. Sci. 28, 525-530.

FULKERSON W. J., HOOLEY R. D., McDOWELL G. H., FELL L. R., 1976. Artificial induction of lactation in ewes: the involvement of progesterone and prolactin in lactogenesis. Aust. J. biol. Sci., 29, 357-363. 
FULKERSON W. J., MCDOWELL G. H., HOLLEY R. D., FELL L. R., 1977. Artificial induction of lactation in ewes : the use of prostaglandin. Aust. J. biol. Sci, 30, 573-576.

HEAD H. H., DELOUIS C., TERQUI M., KANN G., DJIANE J., 1980. Effect of various hormone treatments on induction of lactation in ewes. J. anim. Sci, 50, 706-712.

KANN G., 1971. Dosage radioimmunologique de la prolactine plasmatique chez les ovins. C.R. Acad. Sci. Paris, sér. D, 272, 2808-2811.

KANN G., CARPENTIER M. C., FĖVRE J., MARTINET J., MAUBON M., MEUSNIER C., PALY J., VERMEIRE N., 1978. Lactation and prolactin in sheep, role of prolactin in initiation of milk secretion, 201-212. In C. ROBYN, M. HARTER, Progress in prolactin physiology and pathology, Elsevier/North-Holland Biomed. Press.

KANN G., DENAMUR R., 1973. Changes in plasma levels of prolactin and LH induced by luteolytic or luteotrophic treatment in intact cycling sheep or after section of the pituitary stalk. Acta endocrinol., 73, 625-634.

KANN G., DENAMUR R., 1974. Possible role of prolactin during the oestrous cycle and gestation in the ewe. J. Reprod. Fert., 39, 473-483.

PALMER E., JOUSSET B., 1975. Urinary oestrogens and plasma progesterone levels in nonpregnant mares. J. Reprod. Fertil., Suppl. 23, 213-221.

PALMER E., TERQUI M., 1977. The measurement of total plasma oestrogens during the follicular phase of the mare's oestrous cycle. Theriogenology, 7, 331-338.

REEVES J. J., ARIMURA A., SCHALLY A. W., 1970. Serum levels of prolactin and luteinizing hormone (LH) in the ewe at various stages of the estrous cycle. Proc. Soc. exp. Biol. Med., 134, 938-942.

SMITH K. L., SCHANBACHER F. L., 1973. Hormone-induced lactation in the bovine. I. Lactational performance following injections of $17 \beta$-estradiol and progesterone. J. Dairy Sci., 56, 738743.

STABENFELDT G. H., DROST M., FRANTI C. E., 1972. Peripheral plasma progesterone levels in the ewe during pregnancy and parturition. Endocrinology, 90, 144-150.

TEROUI M., DRAY F., COTTA J., 1973. Variations de la concentration d'œestradiol-17 $\beta$ dans le sang périphérique de la Brebis au cours du cycle œstral. C.R. Acad. Sci. Paris, sér. D, 277, 1795-1798. 